\title{
Impact of ISO 9000 Certification on TQM Practices: Empirical Study in Ethiopian Manufacturing Companies
}

\author{
Dr. R. Satya Raju ${ }^{1}$, Haile Yeshanew Baye ${ }^{2}$ \\ ${ }^{1}$ Professor and Research Director, Dept. of Commerce \& Management Studies, Andhra University, Visakhapatnam - 530003
}

${ }^{2} \mathrm{PhD}$ Scholar, Dept. of Commerce \& Management Studies, Colleges of Arts and Commerce, Andhra University, Visakhapatnam - 530003

\begin{abstract}
ISO 9000 certification is one of the most widely accepted quality assurance systems in world-wide. The primary objective of this study is to examine the relationship between ISO 9000 certification and the levels of total quality management practices of medium and large manufacturing firms in Ethiopia. The design of this research has quantitative approach. Both ISO9000 certified and noncertified firms are included in the survey. From 300 sampled medium and large manufacturing firms a total of 122 valid responses were received. The collected data were analyzed using descriptive analysis such as mean and standard deviation.Inferential statistics was done through T-test.The findings indicate that ISO 9000 certified companies show higher levels of total quality management practices in top management leadership, supply quality management, process management and continuous improvement. Furthermore, the study concludes that when ISO 9000 and TQM are implemented simultaneously, the subsequent benefits to the company are better than those experienced if TQM were implemented in separation.
\end{abstract}

Keywords: Total Quality Management, ISO: 9000 Series, Quality management, Organization Performance, Manufacturing Firms

\section{Introduction}

International organization of standards (ISO), a global federation of 130 national standards bodies, seeks to promote standardization and the development of related activities worldwide in order to facilitate the international exchange of goods and services, and cooperation in the sphere of intellectual, scientific, technological and economic activities [1]. ISO: 9000 Seriesof standards was first published by the International Organization for Standardization (ISO) in 1987 and was subsequently updated in 1994 and 2000 [2].ISO 9000 has gained in popularity as the number of certifications that have been issued increased to more than 1, 609 294in worldwide in 2014[3]. A number of researchers reported that ISO 9000 certified companies had improved quality management practices and quality results more effectively than those companies without ISO 9000 registration and certification.However,rare empirical research has been conducted in this area in Ethiopia. Studies related to the impact of ISO 9000 on the level TQM practices in Ethiopia's manufacturing industry have not been found in the literature review thus far. Therefore, the primary aims of this study is to examine the relationship between ISO 9000 certification and the levels of total quality management practices of medium and large manufacturing firms in Ethiopia.

\section{Literature Review}

\subsection{ISO: 9000 Series and TQM}

ISO 9000 is a process that typically shifts an organization's culture to allow successful Total Quality Management (TQM) implementation. Studies reported that companies that implement ISO9000 and TQM at the same time and in an integrated manner might expect to have advantages in product quality, delivery, productivity and customer satisfaction [1]. Bikshapathi[4] reported that in his study there is strong relation between the ISO certification and TQM implementation. The author also found that the total quality management is implemented in organizations with ISO certification were better than those of without ISO certification. Companies that are internally motivated to implement ISO 9000 should a high level of TQM elements [5].According to Kuo et al [6], the development and certification of an ISO 9000 quality assurance system really improves TQM performance. He also found that all certified divisions experience significant results on the level of quality management practices regardless of the nature, size and length of practices.

On the other side, ISO9000 certification is only the beginning of a continuous improvement process rather than the end and could be a useful stepping stone for TQM. ISO 9000 can be an excellent start to TQM, if it is interpreted in a way that encourages the company to start on the process of continual improvement by team work of all people working in the company satisfaction[1]. Furthermore, Quazi et al. [2]suggests that ISO 9000 registration does not have any impact on quality management practices and quality results for firms. Martinez-Lorente et al. [7]also reported that ISO 9000 does not contribute to improve results, especially when the company is also applying a TQM policy, which does contribute to improve them.ISO 9000 certification does not guarantee improved performance due to the high explicit and implicit costs associated with its implementation [8]. Generally, different studies have been conducted in these areas. However, there is no agreement on the relationship between ISO 9000 certification and TQM practices. In this study, ISO 9000 certified companies would, therefore, be expected to have more effective TQM practices than none certified companies as a result of their ISO 9000 effort. 


\section{International Journal of Science and Research (IJSR) \\ ISSN (Online): 2319-7064}

Index Copernicus Value (2013): 6.14 | Impact Factor (2015): 6.391

\subsection{TQM and Organization Performances}

TQM is a holistic and right-minded advance of the firms to continuously improve their products/services or processes involving all stakeholders in order to satisfy their customers and to enhance performance and sustainability [9].Many firms have arrived at the conclusion that effective TQM implementation can improve their customer satisfaction and organization performance[10]. The critical success factors of TQM can be described as best practices or ways in which firms \& their employees undertake business activities in all key processes. According to Dean \& Bowen [11], TQM as a philosophy or an approach to management can be characterized by its Critical Success Factors. They continue and indicate that TQM implementation can only be accomplished through a set of Critical Success Factors that supports the TQM philosophy.Based on literature review, six critical success factors are adopted as a TQM construct for this study. These CSFs are also used by Abusa [12] and empirically proved different TQM scholars (see Table 1).

Table 1: TQM critical success factors supported by different researchers

\begin{tabular}{|c|c|}
\hline Critical success factor of TQM & Supported studies \\
\hline Top Management Leadership \& Commitment & {$[13,14,6,15,16,17,9]$} \\
\hline Customer Focus & {$[13,2,18,19,20,15,9]$} \\
\hline Supplier Quality Management & {$[6,15,16,9]$} \\
\hline People Management & {$[18,21,19,22,16,23]$} \\
\hline Process Management & {$[24,25,26,20,16]$} \\
\hline Continuous Improvement & {$[27,28,29,30,31]$} \\
\hline
\end{tabular}

Organizational performance is possibly the most widely used dependent variable in organizational research today. However, at the same time it remains one of the most vague and loosely defined constructs [32]. A review of past empirical studies on organizational performance also indicatesthat there are variations in measuring performance in organizations[33,34]. To date, no uniform measures have existed. To investigate the relationship between TQM practices and organization performance improvement, this study incorporates different indictors of overall performance such as customer result, employee result, product quality results and key business result as supported by different researchers and quality award models (see Table 2).

Table 2: Organization performance indicators supported by different studies

\begin{tabular}{|l|l|}
\hline Overall OP indicators & Supported studies \\
\hline Employee Result & {$[35,36,37,38,39]$} \\
\hline Product Quality Result & {$[40,41,42,43,44]$} \\
\hline Customer Result & {$[36,45,12,46,47]$} \\
\hline Key business Result & {$[48,49,34,46]$} \\
\hline
\end{tabular}

\section{Research methodology}

\subsection{Questionnaire}

To investigate the relationship between ISO 9000 certification, TQM implementation status and organization performance, structured survey questionnaire was used for data collection. Based on the comprehensive review of TQM literature, a total of 6 Total Quality Management practice constructs and 4 performance indicators were adopted from several related studies; these are Abusa [12], Zhang [48], Claver et al. [50], Chileshe \& Watson [51], Santos-Vijande \& Alvarez-Gonzalez [52], Das et al. [53], and Anil \& Satish [54]. The questionnaires were tested, and refined, by means of a Pilot Study and then distributed to all sampled companies and addressed either to the General Manager, Quality and inspection Manager, operation/production manager or some other manager who is responsible for Quality. Following other similar studies Bas [55], Mallur and Hiregoudar [56], Bahri et al. [57] and Ullah [58], a fivepoint Likert scale was employed for scoring responses $(1=$ strongly disagree and $5=$ strongly agree).The questionnaires have 3 main sections. Section 1 covers general information about the responding companies. The Second section are attempted to check the degree of total quality management practices on 6 critical success factors of TQM with a total of 61 statements.Finally, Section 3 describes the degree of agreement achieved on the impact of implementing TQM in organization performances with a total of 23 statements.

\subsection{Population and Sample}

According to the 2010-2011 annual Large and Medium Scale Manufacturing industries survey of Ethiopian Central Statistical Agency [59], the total numbers of medium and large manufacturing firms located in the industrial area of Addis Ababa were 870. A total 300 medium and large manufacturing firms from the list were selected using simple randomly sampling technique. Both ISO 9000 certified and non-certified firms are included in the sample. The questionnaires were sent out using the face to face method for data collection to the targeted managers. Finally, 136 questionnaires were returned.According to their response 122 firms implemented TQM or, more specifically, part of TQM for the last three years. Therefore, 122 usable questionnaires were obtained for analysis purpose for the study. The usable questionnaire rate was $40.67 \%$, normal for such research.

\subsection{Methods of data analysis}

The responses were assigned numeric codes and data entered into a SPSS (version 20.0) file for statistical analyses. Descriptive statistical analyses were conducted for demographic variable for the research respondent companies' i.e. industry type, certification status, etc. The validity of the instrument was conducted by a wide review of the literature and by using experts' feedback of quality and operations management in the industry. The reliability of the 6 critical factors of TQM and 4 performance indicators were calculated by Crobach's alpha (see Table 3 ). Nunnally[60]advocates that reliability coefficients of 0.70 or more are considered good, although it may be reduced to 0.6 in exploratory research [61]or even to 0.55 [62]. Based on the table, value of Cronbach's $\alpha$ was well above the criteria. So, it can be concluded that the instrument used in this study was valid and reliable.

Mean for individual items and over all mean for each construct were calculated to analyze the current level of TQM practices and organization performance improvement. T-test of Hypothesis for the Mean Difference also used to see the significance difference between ISO 9000 certified 


\section{International Journal of Science and Research (IJSR) \\ ISSN (Online): 2319-7064}

Index Copernicus Value (2013): 6.14 | Impact Factor (2015): 6.391

and non-certified company. Correlation analyses were conducted to observe the degree of relationship between TQM critical success factors and performance indicators.

Table 3: Reliability analysis of critical success factors of TQM and OP indicators

\begin{tabular}{|c|c|c|c|}
\hline No. Variables/Indicators & $\begin{array}{c}\text { No. of } \\
\text { items }\end{array}$ & $\begin{array}{c}\text { Cronbach's } \\
\alpha\end{array}$ & Description \\
\hline 1. TQM Practices (X) & & & \\
\hline Top management Leadership & 12 & 0.901 & Reliable \\
\hline Customer focus & 11 & 0.846 & Reliable \\
\hline Supplier management & 7 & 0.814 & Reliable \\
\hline People management & 12 & 0.896 & Reliable \\
\hline Process management & 10 & 0.856 & Reliable \\
\hline Continuous improvement & 8 & 0.799 & Reliable \\
\hline 2. overall performance (Y1) & & & \\
\hline Employee Result & 6 & 0.860 & Reliable \\
\hline Quality Result & 7 & 0.786 & Reliable \\
\hline Customer Result & 6 & 0.826 & Reliable \\
\hline Key Business Result & 4 & 0.769 & Reliable \\
\hline
\end{tabular}

\section{Results and Discussions}

\subsection{General Profile of Respondent Companies}

The response rate of the survey was $40.67 \%$. The majority of individuals who participated in this research were having position within the company as a quality and inspection manager (54.9\%), having level of education Bachelor degree $(61.5 \%)$ with a science background $(43.4 \%)$ (seeTable 4$)$. It is very clear that the questionnaire were completed by the person who is responsible for quality in the company. Furthermore, all participants possessed minimum Bachelor's Degree and have sufficient knowledge on quality management system as well as a good understanding of the terminology used in the questionnaire.

The participant companies were from eight different industry groups which is the: Food \& Beverage(26.2\%), Metal \& Steel (15.6\%), Leather \& Textile Industry (19.7\%), Chemical (12.3\%), Building material (4.9\%), Wood \& Furniture (8.2\%), Electric \& Electronics (5.7\%) and Plastics $\&$ other industries $(7.4 \%)$. It is clear that the wide area of manufacturing industrial groups of Ethiopian economy has been well covered.

As it was the purpose of this study to find out where the Ethiopian companies are in the quality race, the companies were asked whether they have been certified with ISO 9000. Only $32.8 \%$ of the respondent companies already have an ISO certification. Most (67.2\%) of the respondents do not have an ISO 9000 certification. This clearly shows that the involvement in ISO 900 certification is very low, where they were not realized the importance of ISO certification at their company. Table 4 , also shows that $56.1 \%$ of non-certified firms have a plan to get certification in short period. Perhaps, the remaining (43.9) are still in their infancy stage of getting to the idea of to have ISO 9000 certification for their company.
Table 4: General Profile of Respondent Companies

\begin{tabular}{|c|c|c|c|}
\hline No. & Formal Position & $\begin{array}{c}\text { NO. of } \\
\text { respondents }\end{array}$ & Percent \\
\hline \multirow[t]{3}{*}{ Q1 } & Quality and Inspection Head & 67 & 54.9 \\
\hline & Production Manager & 21 & 17.2 \\
\hline & General Manager & 34 & 27.9 \\
\hline \multirow[t]{3}{*}{ Q2 } & \multicolumn{3}{|c|}{ Highest Education Level } \\
\hline & Bachelor Degree & 75 & 61.5 \\
\hline & Master Degree & 47 & 38.5 \\
\hline \multirow[t]{4}{*}{ Q3 } & Educational Background & & \\
\hline & Engineering & 43 & 35.2 \\
\hline & Business & 26 & 21.3 \\
\hline & Science & 53 & 43.4 \\
\hline \multirow[t]{9}{*}{ Q4 } & \multicolumn{3}{|l|}{ Industry type } \\
\hline & Food and Beverage Industry & 32 & 26.2 \\
\hline & Metal, Steel and Mineral Industry & 19 & 15.6 \\
\hline & Leather and Textile Industry & 24 & 19.7 \\
\hline & Chemical Industry & 15 & 12.3 \\
\hline & Building material industry & 6 & 4.9 \\
\hline & Wood and Furniture Industry & 10 & 8.2 \\
\hline & Electric and Electronics industries & 7 & 5.7 \\
\hline & Plastics and other industry & 9 & 7.4 \\
\hline \multirow[t]{3}{*}{ Q5 } & \multicolumn{3}{|c|}{ Firm classification based on ISO 9000 certification } \\
\hline & Certified & 40 & 32.8 \\
\hline & None Certified & 82 & 67.2 \\
\hline \multirow[t]{3}{*}{ Q6 } & \multicolumn{3}{|c|}{ planning to get certification } \\
\hline & Yes & 46 & 56.1 \\
\hline & No & 36 & 43.9 \\
\hline
\end{tabular}

\subsection{Levels of Implementation for TQM Practices}

Mean for individual question and over all mean for each 6 dimension were calculated to analyze the implementation levels of TQM practices. For easier interpretation of the results of the study, researcher refers to the interpretation of scores $1.00-1.80=$ worst, $1.80-2.60=$ low, 2.60-3.40= enough, $3.40-4.20=$ high and $4.20-5.00=$ very high $[63,57,64]$.

Table 5: Results for Mean Value \& Std. deviation of TQM Practices

\begin{tabular}{|l|l|l|l|}
\hline No. & Variables/CSF & Mean & SD \\
\hline & TQM Practices & 3.17 & .402 \\
\hline 1 & $\begin{array}{l}\text { Top Management leadership \& } \\
\text { commitment }\end{array}$ & 3.17 & .393 \\
\hline 2 & Customer Focus & 3.00 & .434 \\
\hline 3 & People Management & 3.30 & .461 \\
\hline 4 & Supplier Quality Management & 2.97 & .500 \\
\hline 5 & Process Management & 3.32 & .513 \\
\hline 6 & Continuous Improvement & 3.24 & .595 \\
\hline
\end{tabular}

According to table 5, it can be reveals that average value (mean) of TQM practices variable was in moderate category (3.17). The values of the six critical success factor range from 2.97 to 3.32 , which corresponds to a 'moderate' level of practice. People Management (3.30) and Continuous Improvement (3.32) were the two highest practices in this study; while Supplier Management (2.97) and Customer Focus (3.00) was the bottom two (see Table 5). From this result, it can be observed that all the respondents rated at 'moderate' for degree of TQM practices in their companies, indicating that companies are struggling to practice TQM successfully. 


\section{International Journal of Science and Research (IJSR)}

ISSN (Online): 2319-7064

Index Copernicus Value (2013): 6.14 | Impact Factor (2015): 6.391

\subsection{Levels of organization performance (OP) Improvement}

To analyze the organization performance improvement level over the last three years the researcher uses four indicators and 23 items questionnaire. Mean for individual question and over all mean for each 4 indicators were calculated. The overall mean values of each indicators range from 3.15 to 3.50 shown in Table 6 .

Table 6: Mean values \& Std. Deviations of organizational performance improvement

\begin{tabular}{|l|l|l|l|l|}
\hline No. & Indicators & Mean & SD & Description \\
\hline & Organization Performance & 3.39 & & \\
\hline & Employee Result & 3.50 & .502 & High \\
\hline & Product Quality Result & 3.44 & .495 & High \\
\hline & Customer Result & 3.15 & .585 & Enough \\
\hline & Key Business Result & 3.45 & .566 & High \\
\hline
\end{tabular}

Table 6 indicates that average value (mean) of performance improvement variable was a little between the 'moderate' and 'high' improvement category (3.39). The values of the 4 performance indicators range from 3.15 to 3.50 , which corresponds to between 'moderate' and 'high' level of performance improvement. Employee result (3.50) and key business result (3.45) were the two highest performance improvement in this study; Customer result (3.15) was the bottom one (see Table 6). From this result, it can be observed that all the respondents rated at between 'moderate' and 'high' for degree of performance improvement in their companies, indicating that companies are struggling to improve organization performance from different angle.

\subsection{Comparison between ISO 9000 certified and non- certified Firms on Level of TQM Implementation}

Comparative data on ISO 9000 certified and non-certified manufacturing firms are provided in Table 7. From Table 7, mean measures on the four categories defining the TQM practices were significantly greater for the ISO 9000 certified group than none certified group.

Table 7: Comparison between ISO 9000 certified and noncertified Firms on Level of TQM Implementation

\begin{tabular}{|c|c|c|c|c|c|c|}
\hline CSF & \multicolumn{2}{|c|}{$\begin{array}{c}\text { ISO 9000 } \\
(\mathrm{n}=40)\end{array}$} & \multicolumn{2}{c|}{$\begin{array}{c}\text { Non ISO } \\
9000(\mathrm{n}=82)\end{array}$} & $\mathrm{T}_{\text {cal }}$ & $\mathrm{P}_{\text {value }}$ \\
\cline { 1 - 5 } & Mean & SD & Mean & SD & & \\
\hline $\begin{array}{c}\text { TQM } \\
\text { Practices }\end{array}$ & 3.42 & & 3.04 & & & \\
\hline TMlC & 3.24 & .229 & 3.13 & .293 & 1.99 & .049 \\
\hline CF & 3.10 & .403 & 2.95 & .442 & 1.831 & .070 \\
\hline PPM & 3.37 & .421 & 3.26 & .478 & 1.317 & .190 \\
\hline SM & 3.13 & .450 & 2.89 & .506 & 2.566 & .012 \\
\hline PRM & 3.66 & .364 & 3.15 & .494 & 5.770 & .000 \\
\hline CI & 3.53 & .334 & 3.06 & .448 & 5.858 & .000 \\
\hline
\end{tabular}

As it was already anticipated that TQM practices among the ISO 9000 certified companies are supposed to be higher than ISO 9000 non-certified companies was proven to be true at all critical success factors. On four of the six TQM critical success factors, there are significant differences between the mean responses of the ISO 9000 certified and non-certified respondent companies.
In particular, the p-value of the t-test shows that the participants perceived that the ISO 9000 certified companies had greatest significance difference in Process Management (.000) and Continuous improvement (.000), followed by Supplier Management (.012). Interestingly, the least significance difference between the mean measures of the ISO 9000 certified and non-certified firms were measures for Top Management leadership \& commitment (.049). The results are in agreement with the results reported by Kuo et al. [6]ISO certifications significantly improve the effectiveness of quality management practices, and providing a good first step towards TQM. The results are also in agreement with the result reported by Bikshapathi [4]that total quality management is implemented in organizations with ISO certification were better than those of without ISO certification.

\subsection{Comparison between ISO 9000 Certified and Non- Certified Firms on Level of OP}

Table 8: Comparison between ISO 9000 certified and noncertified Firms on Level of OP

\begin{tabular}{|c|c|c|c|c|c|c|}
\hline OP indicators & \multicolumn{2}{|c|}{$\begin{array}{c}\text { ISO 9000 } \\
\text { certified } \\
(\mathrm{n}=41)\end{array}$} & \multicolumn{2}{c|}{$\begin{array}{c}\text { ISO 9000 } \\
\text { non-Certified } \\
(\mathrm{n}=81)\end{array}$} & \multirow{2}{*}{$\mathrm{T}_{\text {cal }}$} & $\mathrm{P}_{\text {value }}$ \\
\hline & Mean & SD & Mean & SD & & \\
\hline Overall Op & $\mathbf{3 . 5 9}$ & & $\mathbf{3 . 2 9}$ & & & \\
\hline People Result & 3.77 & .382 & 3.37 & .503 & 4.43 & .000 \\
\hline Quality result & 3.72 & .362 & 3.31 & .495 & 4.75 & .000 \\
\hline Customer result & 3.28 & .515 & 3.09 & .610 & 1.69 & .093 \\
\hline Key B. Result & 3.59 & .414 & 3.38 & .618 & 1.91 & .059 \\
\hline
\end{tabular}

From Table 8, the result reveals that the influence of TQM practices on organizational performance is higher for those ISO 9000 certified companies. On two of four OP indicators, there are significant differences between the mean responses of the ISO 9000 certified and non-certified respondent companies. In particular, the p-value of the t-test shows that the influences of TQM practices had greatest significance difference in People Result (.000) and Product quality Results (.000) between ISO 9000 certified and non-certified companies.

This result was consistent with the results reported by Kuo et al. [6]. ISO certification does bring significant benefits to improve the level of quality performance. Starke et al. [65]also believed that certification contributes to increase in sales revenues, decrease in cost of goods sold/sales revenue and increase in the asset turnover ratios.Hasan et al. [1] also found that companies that implement ISO9000 and TQM at the same time and in an integrated manner have better performance in product quality, delivery, productivity and customer satisfaction. Muturi et al. [66]also reported that certified companies have better return on net assets of the organizations thereby influencing their performance.

\subsection{Correlation Analysis between variables}




\section{International Journal of Science and Research (IJSR) \\ ISSN (Online): 2319-7064}

Index Copernicus Value (2013): 6.14 | Impact Factor (2015): 6.391

Table 9: Pearson Correlation coefficient matrix

\begin{tabular}{|l|l|c|c|c|c|}
\hline \multicolumn{2}{|c|}{} & CR & PQR & ER & KBR \\
\hline \multirow{2}{*}{ TM } & PC & .600 & $.655^{* *}$ & $.638^{* *}$ & $.419^{* *}$ \\
\cline { 2 - 6 } & Sig. & .000 & .003 & .000 & .000 \\
\hline \multirow{2}{*}{ CF } & PC & $.529^{* *}$ & $.549^{* *}$ & $.545^{* *}$ & $.406^{* *}$ \\
\cline { 2 - 6 } & Sig. & .000 & .000 & .000 & .000 \\
\hline \multirow{2}{*}{ PP } & PC & $.447^{* * *}$ & $.469^{* *}$ & $.504^{* *}$ & $.356^{* * *}$ \\
\cline { 2 - 6 } M & Sig. & .000 & .000 & .000 & .000 \\
\hline \multirow{2}{*}{ SQ } & PC & .083 & $.264^{* *}$ & $.255^{* *}$ & .171 \\
\cline { 2 - 6 } M & Sig. & .361 & .003 & .005 & .060 \\
\hline CI & PC & $.610^{* *}$ & $.585^{* *}$ & $.666^{* *}$ & $.384^{* *}$ \\
\cline { 2 - 6 } & Sig. & .000 & .000 & .000 & .000 \\
\hline \multirow{2}{*}{ PR } & PC & $.570^{* *}$ & $.575^{* * *}$ & $.396^{* *}$ & $.312^{* * *}$ \\
\cline { 2 - 6 } M & Sig. & .000 & .000 & .000 & .000 \\
\hline
\end{tabular}

As shown in the above Table 9, the result also revealed that entire six TQM critical success factor is significantly correlated with all performance improvements except supply quality management. Supply quality management is significantly correlated only with two performance indicators: product quality result (.264) and employee result (.255). TMLC has highest and significant correlation with entire performance improvements; it is significantly correlated with customer Result (.600), product quality performance (.655), employee performance (.638) and key business results (.419). This result is consistent with the study conducted byCetinderea et al. (2015) that leadership criteria have a higher correlation with performance.

TQM critical success factor vary in terms of their importance to influence the four performance improvements. It was observed firstly that TMLC, as a TQM critical success factor could be rated as the most important TQM critical success factor in relation to organizational performance improvements. The second most important TQM critical success factor was continuous improvement with higher correlation coefficient. This was a significant predictive factor that explained variations in the entire organizational performance improvements. The influence supply quality managementwas very low and it was influence only two performance improvements i.e., product quality performance and employee performance.

\section{Conclusion, Limitations and Future Directions}

This paper has presented the results of a study conducted on Ethiopian manufacturing firms, with the primary objective of investigating the relationship between ISO 9000 certification, TQM practice and Organization performance improvement in these firms. Classification has been done by ISO 9000 certification status. The results vary to a certain degree between groups, and significant difference was found on four TQM critical success factors \& two performance indicators. Manufacturing companies in Ethiopia that certified ISO 9000 standards is necessarily obtain better TQMpractices and performance improvement than those that had not yet certified. The implication is that ISO 9000 standards \& TQM must be completely and systematically implemented and integrated which in turn should lead to improve organization performance.The study should be better if it is done by balanced number of certified and noncertified firms. But this could not be done in this study owing to small number of firms which are ISO 9000 certified in the country. As ISO 9000 is becoming well accepted and more firms are going in for certification, the next study can address this issue.

\section{References}

[1] Hasan M, Ali MM, Lam HK. ISO9000 and TQM for Business Excellence. Kaohsiung: National Sun Yat-sen University; 2007.

[2] Quazi HA, Hong CW, Meng CT. Impact of ISO 9000 certification on quality management practices: A comparative study. Total Quality Management. 2002;13(1):53-67.

[3] the International Organization for Standardization, ISO. ISO. [Internet]. 2014 [cited 2016 Feb 18]. Available from: http://www.iso.org.

[4] Bikshapathi V. IMPACT OF ISO CERTIFICATION ON TQM PRACTICES IN SMALL AND MEDIUM ENTERPRISES. International Journal of Multidisciplinary Research. 2011;1(8):403-418.

[5] Martinez Lorente AR, Martinez-Costa. simultaneous consideration of TQM and ISO 9000 on performance and motivation: an empirical study of Spanish companies. International Journal of production economics. 2008;13(1).

[6] Kuo T, Chang TJ, Hung Kc, Lin M. Employees' perspective on the effectiveness of ISO 9000 certification: A Total Quality Management framework. Total Quality Management \& Business Excellence. 2009;20(12):1321-1335.

[7] Martinez-Lorente AR, Dewhurst, F, Dale, B.G. Total Quality Management: Origin and Evolution of the Term. The TQM Magazine. 1998;10(5):378-386.

[8] Van der Wiele T, Van Iwaarden J. Perceptions about the ISO 9000:2000 quality system standard revision and its value: Dutch experience. International Journal of Quality and Reliability Management. 2005;22(2):101119.

[9] Sadikoglu E, Olcay. The Effects of Total Quality Management Practices on Performance and the Reasons of and the Barriers to TQM Practices in Turkey. Advances in Decision Sciences. 201417.

[10] Arawti A, Mokhtar, A. Total Quality Management practice in manufacturing companies in Malaysia: an explotory analysis. Tota quality management. 2000b;11(8).

[11]Dean W, Bowen. Management Theory and Total Quality: Improving Research and Practice through Theory Development. The Academy of Management Review. 1994;19(3):392-418.

[12] Abusa F. TQM implementation and its impact on organisational performance in developing countries: a case study on Libya,Doctor of Philosophy thesis. Australia: Faculty of Engineering, University of Wollongong; 2001.

[13] Samson D, Terziovski. The relations between total quality management practices and operational performance. Journal of Operations Management. 1999;17(4):393-409.

[14] Nofal AA, Omaim N, Zairi M. Critical Factors of TQM: An Update on The Literature. International Journal of Applied Quality Management. 2005;2(2):1-15. 


\section{International Journal of Science and Research (IJSR) \\ ISSN (Online): 2319-7064}

Index Copernicus Value (2013): 6.14 | Impact Factor (2015): 6.391

[15] Shahin A, Dabestani R. A feasibility study of the implementation of total quality management based on soft factor. Journal of industrial Engineering and management. 2011;4(2):250-280.

[16] Fening FA, Amaria , Frempong O. Linkages between Total Quality Management and Organizational Survival in Manufacturing Companies in Ghana. International Journal of Business and Social Science. 2013;4(10):115.

[17] Mardani A, Bagheri MM, Soltan EKH, Lari MK. Relationship between National Culture and Soft Total Quality Management in Iranian Multinational Firms. International Journal of Basic and Applied Science. 2013;02(01):160-172.

[18] Talavera GV. TQM ADOPTION AND FIRM PERFORMANCE IN THE PHILIPPINES. Philippine Management Review. 2005;12:23-44.

[19] Talib , Rahman Z, Qureshi MN. The relationship between total quality management and quality performancein the service industry: a theoretical model. International Journal of Business, Management and Social Sciences. 2010;1(1):113-128.

[20] Nitin S, Dinesh K, Singh. TQM for manufacturing excellence: Factors critical to success. INTERNATIONAL JOURNAL OF APPLIED ENGINEERING RESEARCH. 2011;2(1):219-233.

[21] Welikala , Sohal AS. Total Quality Management and employees' involvement: A case study of an Australian organisation. Total Quality Management \& Business Excellence. 2008;19(6):627-642.

[22] Thamizhmanii S, Hasan S. A review on an employee empowerment in TQM practice. Journal of Achievements in Materials and Manufacturing Engineering. 2010;39(2):204-210.

[23] Swamy , C.M S, A. S. Total Quality Management \& Human Resource Issues:A Hypothetical Analysis. Acme Intellects International Journal of Research in Management. 2013;2(2):1-15.

[24] Chang PL, Lu KH. Current status of total quality management implementation in Taiwan companies. The TQM Magazine. 1995;7(1):14-19.

[25] Kasul , Motwani J. Total quality management in manufacturing: Thematic factor Assessment. International Journal of Quality \& Reliability Management. 1995;2(3):57-76.

[26] Motwani J. Critical factors and performance measures of TQM. The TQM Magazine. 2001;13(4):292-300.

[27] Dahlgaard JJ, Kristensen K, Kanji GK, Juhl HJ, Sohal AS. Quality management practices: a comparative study between East and West. International Journal of Quality and Reliability Management. 1998;15(8/9):812-826.

[28] Chin KS, Pun KF. Proposed Framework for Implementing TQM in Chinese Organisations. International Journal of Quality \& Reliability Management. 2002;19(3):272-294.

[29] Boer H, Gertsen F. From Continuous Improvement to Continuous Innovation. International Journal of Technology Management. 2003;26(6):805-827.

[30] Samat N, Ramayah T, Saad NM. TQM Practices, Service Quality, and Market Orientation: Some Empirical Evidence from A Developing Country. Management Research News. 2006;29(11):713-728.
[31]Hand M. Freeing the Victims. The TQMMagazine. 1993;5(3):11-14.

[32] Rogers Ew, Wright PM. Measuring organizational performance in strategic human resource management: Problems and prospects. CAHRS Working Paper. 1998 98-109.

[33] Monge CAM, Rao SS, Gonzalez ME, Sohal AS Performance measurement of AMT: a crossregional study. Benchmarking. An International Journal. 2006;13(1/2):135-146.

[34]Zakuan NM, Yusof, S.M, Shamsudin, S, Laosirihongthong, T. Reflective Review of Relationship between Total Quality Management and Organizational Performance. In: Proceedings of International Conference on Mechanical \& Manufacturing Engineering (ICME2008; 2008; Johor Bahru,Malaysia.

[35] Locke EA. The nature and causes of job satisfaction, Handbook of industrial and organisational psychology. Chicago: Rand McNally; 1976.

[36] Naumann E, Giel K. Customer Satisfaction Measurement and Management. Boise, Idaho: Thomson Executive Press ; 1995.

[37] Moorehead G, GriffinRW. Managing people and organisations. Boston: Houghton Mifflin; 1998.

[38] Mak B, Sockel H. A confirmatory factor analysis of IS employee motivation and retention. Information and Management. 2001;35(5):265-276.

[39] Chang HH. Development of performance measurement systems in quality management organizations. The Service Industries Journal. 2006;26(7).

[40] Ahire SL, Landeros , Golhar D. Total Quality Management: A Literature Review and an Agenda for Future Research. Production and Operations Management. 1995 277-307.

[41] Kaynak H. The relationship between total quality management practices and their effects on firm performance. Journal of Operations Management. 2003;21(4):405-435.

[42] Prajogo DI, Sohal. The multidimensionality of TQM practices in determining quality and innovation:an empirical examination. Technovation. 2004;24:443-453.

[43] Hassan Mu, Mukhtar, Qureshi SU, Sharif. Impact of TQM Practices on Firm's Performance of Pakistan's Manufacturing Organizations. International Journal of Academic Research in Business and Social Sciences. 2012;2(10):232-259.

[44]Zehira C, Ertosunb , Zehirc S, Muceldillid B. Total Quality Management Practices' Effects on Quality Performance and Innovative Performance. Social and Behavioral Sciences. 2012;41:273 - 280.

[45] Naumann E, Jackson DW, Rosenbaum Ms. How to implement a customer satisfaction program. Business Horizons. 2001;44(1):177-207.

[46] Raja W, Bodla , Malik. Evaluating the Effect of Total Quality Management Practices on Business Performance: A Study of Manufacturing Firms of Pakistan. International Journal of Business and Social Science. 2011;2(9):110-117.

[47] Mahmoodifar A, Ranjbar M, Rahmani. Study of the Effects of Total Quality Management (TQM) on Customer Satisfaction at Telecommunication Company. American Journal of Life Science. 2014;2(1):125-136. 


\section{International Journal of Science and Research (IJSR) \\ ISSN (Online): 2319-7064}

Index Copernicus Value (2013): 6.14 | Impact Factor (2015): 6.391

[48]Zhang Z. Implementation of Total Quality Management: An Empirical Study of Chinese Manufacturing Firms. Groningen: University of Groningen; 2000.

[49] Douglas TJ, Judge. Total Quality Management Implementation and Competitive Advantage: The Role of Structural Control and Exploration. Academy Management Journal. 2001;44(1):158-169.

[50] Claver , Tari J, Molina J. Critical factors and results of quality management:An empirical study. Total Quality Management \& Business Excellence. 2003;14(1):91118.

[51]Chileshe , Watson. The measurement of quality management levels within UK construction SME's: development and validation of TQ-SMART. In: Khosrowshahi, F (Ed.), 20th Annual ARCOM Conference; 2004; Heriot Watt University, Hilly Edinburgh. p. 77-88.

[52] Santos-Vijande M, Alvarez-Gonzalez LI. TQM and firms performance: An EFQM excellence model research based survey. Int. Journal of Business Science and Applied Management. 2007;2:21-41.

[53] Das A, Paul , Swiercze W. Developing and validating total quality management (TQM) constructs in the context of Thailand's manufacturing industry. Benchmarking: An International Journal. 2008;15(1):52-72.

[54] Anil AP, Satish KP. Empirical Research on TQM Practices of Organizations - Development and Validation of Critical Factors. INTERNATIONAL JOURNAL OF ENGINEERING DEVELOPMENT AND RESEARCH. 2013 32-37.

[55]Bas T. AN EMPIRICAL STUDY ON QUALITY MANAGEMENT PRACTICES IN TURKEY. ZKU Social Sciences journal. 2008;4(7):23-32.

[56] Mallur SB, Hiregoudar NL. A Survey of TQM Practices in North Karnataka Manufacturing SMEs: an Empirical Evaluation. In: Proceedings of the World Congress on Engineering 2010 Vol III; 2010; London, U.K.

[57] Bahri S, Hamzah D, Yus. Implementation of Total Quality Management and Its Effect on Organizational Performance of Manufacturing/Industries Through Organizational Culture in South Sulawesi, Indonesia. IOSR Journal of Business and Management. 2012;5(1):10-24.

[58] Ullah S. Implementation of TQM Practices in Manufacturing Sector of Pakistan. International Journal of the Computer, the Internet and Management. 2012;20(1):57-62.

[59] The Federal Democratic Republic of Ethiopia Central Statistical Agency. Report on Large and Medium Scale Manufacturing and Electricity Industries Survey. addis ababa: ECSA; 2012.

[60] Nunnally JC. Psychometric Theory. 2nd ed. New York: McGraw-Hill; 1978.

[61] Hair JF, Anderson RE, Tatham RC, Black WC. 1Multivariate Data Analysis, With Readings. Englewood Cliffs, NJ: Prentice Hall; 1995.

[62] Van de Ven D, Ferry A. Measuring and Assessing Organizations. New York: Wiley; 1979.

[63] Sugiyono J. Statistics for Research. Bandung, Indonesia: Alfabeta Press; 2008.
[64] Munizu M. The Impact of Total Quality Management Practices towards Competitive Advantage and Organizational Performance:Case of Fishery Industry in South Sulawesi Province of Indonesia. Pakistan Journal of Commerce and Social Sciences. 2013;7(1):184-197.

[65] Starke , Eunni , Dias Fouto NMM, de Angelo F. Impact of ISO 9000 certification on firm performance: evidence from Brazil. Management Research Review. 2012;35(10):974 - 997.

[66] Muturi D, Ochieng , Njihia S. Impact of ISO 9001 Implementation on Organizational Performance in Kenya. Keny inistitute of management. 2015 1-6.

[67] Abas Z, Yaacob Z. Exploring the Relationships between Total Quality Management (TQM), Strategic Control Systems (SCS) and Organizational Performance (OP) Using a SEM Framework. Journal Of American Academy Of Business. 2006;9(2):161-166.

\section{Author Profile}

Mr. Haile Yeshanew is a PhD student under the research director of Professor R. SatyaRaju (PhD) atDept. of Commerce \& Management Studies, Andhra University, Visakhapatnam - 530003 